\title{
3. Teasing out the Tangle: Raskols, Young Men, Crime and HIV
}

\section{VICKI LUKER WITH MICHAEL MONSELL-DAVIS}

\section{Introduction}

This chapter revolves around the 'raskol', a term first used in the mid1960 s to describe young men, usually in groups, who engaged in petty theft and vandalism around Port Moresby, but later became associated with more serious property crime, violence and rape (Harris 1988, 3-16). Deriving from the English word 'rascal', raskolism referred to a new development in the growing town life of what was then the administrative centre of the Australian territories of Papua and New Guinea. Though raskolism still preserves certain connotations of urbanisation and opportunism, so-called raskols are now found in many rural areas while the nature and complexity of criminal activity, including raskolism, has evolved.

Using the raskol as a pivot of discussion here has several justifications for this volume. Raskols remain perhaps the symbol of PNG's 'law and order' problems (see figures 3, 4 and 5; Dupont 2005; Borrey 2000, Dinnen 2001, 55-110) and figure, if less directly, in important contexts for HIV. As adolescents or young men (though some so-called raskols are older and others younger), they belong to the category 'youth' that is a target population for HIV prevention in PNG and globally (Monasch and Mahy 2006; NAC 2006, 12-13; 21, 34, 32). In media accounts and the fears of many women, raskols are also vividly associated with rape, particularly lainap or pack-rape ${ }^{1}$ (see, e.g. Hukula 1999, 8-9; Banks 2000, 93; Borrey $2000,105)$. These practices are of intense concern as crimes in themselves but have serious additional implications for HIV transmission that will be

1 In some circumstances, lainap may involve some kind of 'consent' from the woman and its status as rape can be questionable. This chapter uses the term lainap to apply to cases of group-rape as distinct from groupsex. 
discussed. Moreover, the raskol offers one window onto broader questions of masculinity that, as Eves (this volume) argues, warrant more searching consideration in relation to HIV.

We will argue that some concerns inherent in the raskol tangle of associations distract from other factors that deserve more attention in responses to PNG's law and order challenges and HIV. These include: other dimensions of crime, including 'high end' organised crime and corruption; rape by perpetrators who are not raskols; the broader implications, for HIV, of seemingly non-violent sex (particularly transactional sex broadly defined) and the character of concurrent sexual networks; and, in contrast to vivid anxieties about male youth and raskols, there is a deep need to come to grips with the epidemiologically more significant role of older men in HIV transmission - who are also, arguably, a bigger worry in relation to crime. Finally, while it has long been recognised that HIV prevalence is higher among PNG's female than male youth, this difference must be underscored.

Yet such observations do not weaken the imperative to respond to raskolism in the original senses of the term, or the plight of youth both male and female. The challenges involved are great, not least the difficulty of facilitating new economic opportunities for young people, a point stressed in our conclusion. Many reflections in this chapter draw upon Michael's experience over decades in Papua New Guinea, and his time in Fiji, Samoa and Kiribati, where much of his work has involved youth and witnessed painful social changes (Monsell-Davis 1998a; Hezel 2001; Rubinstein 1994; UNICEF 1995; UNICEF 1998). ${ }^{2}$ This chapter therefore begins with a survey of some of these.

2 This paper was informed by discussions with Michael Monsell-Davis and ideas from his unpublished paper, 'Reflections on Cultures, Social Change and the Spread of HIV in PNG and Oceania'. 
3. Teasing out the Tangle

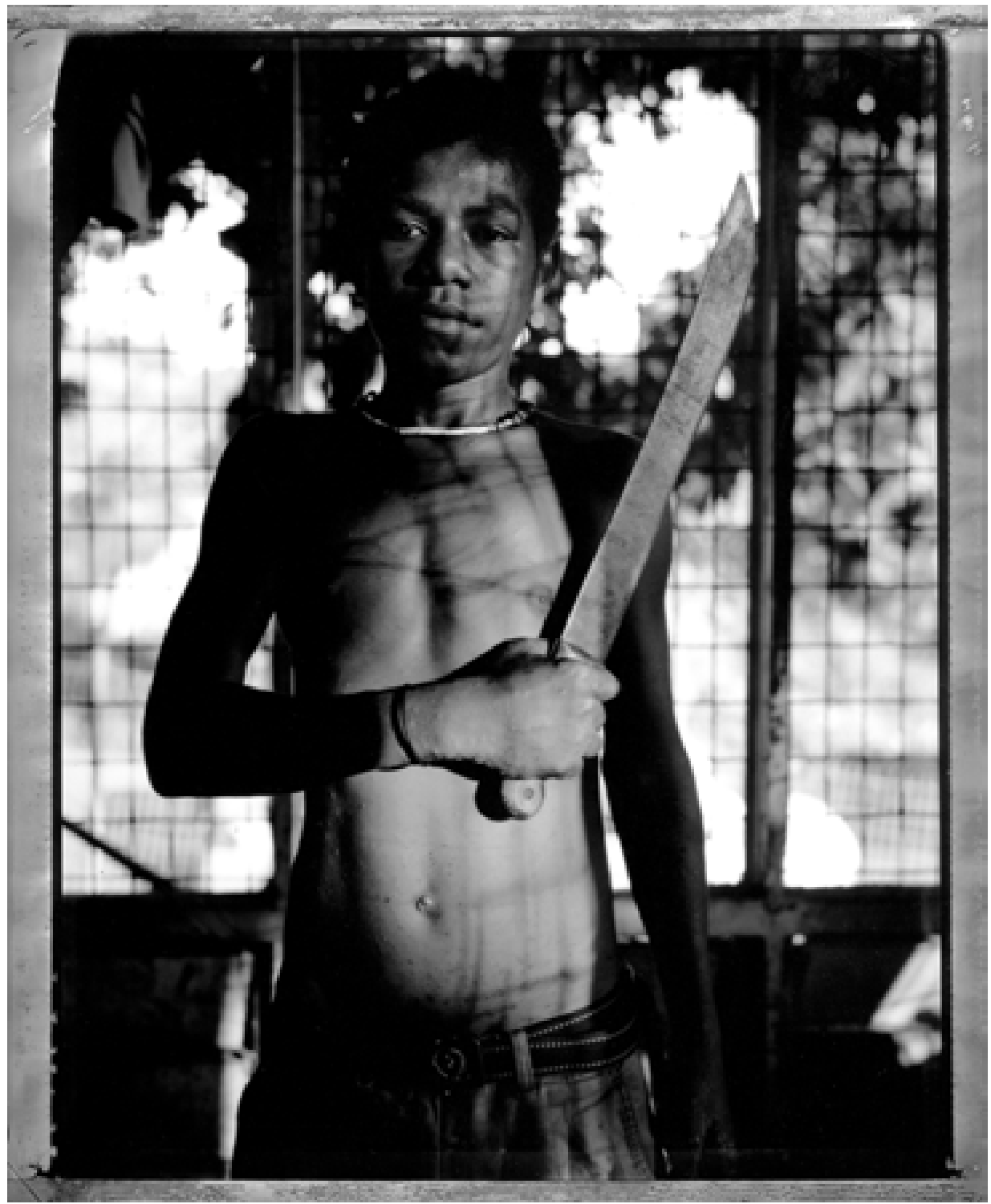

Figure 3: Portrait of Gaitzman, from Kips Kaboni ('Red Devils'), Port Moresby, 2004. Courtesy of Stephen Dupont, www.stephendupont.com 


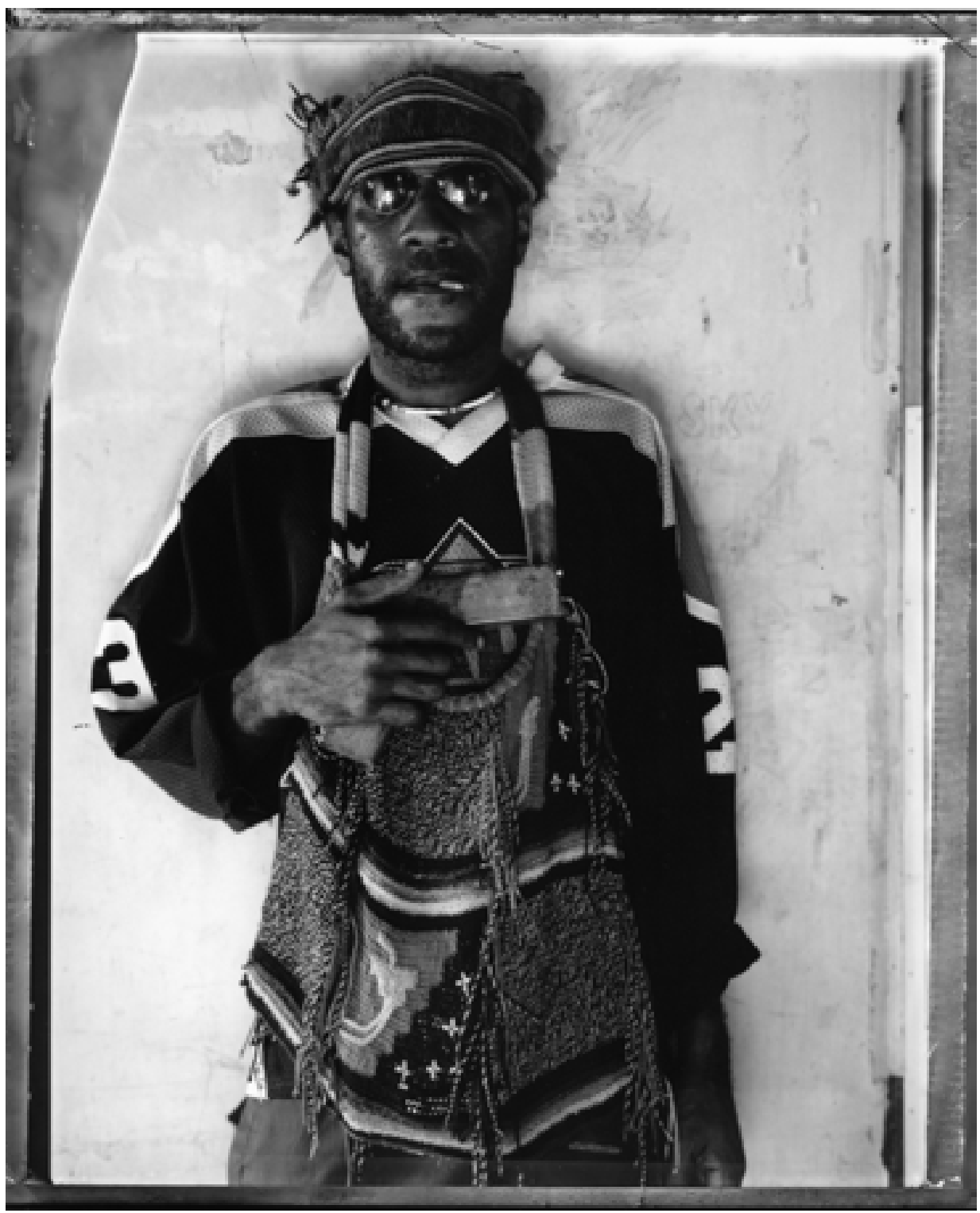

Figure 4: Portrait of Shookman, from Kips Kaboni ('Red Devils'), Port Moresby, 2004. Courtesy of Stephen Dupont, www.stephendupont.com 


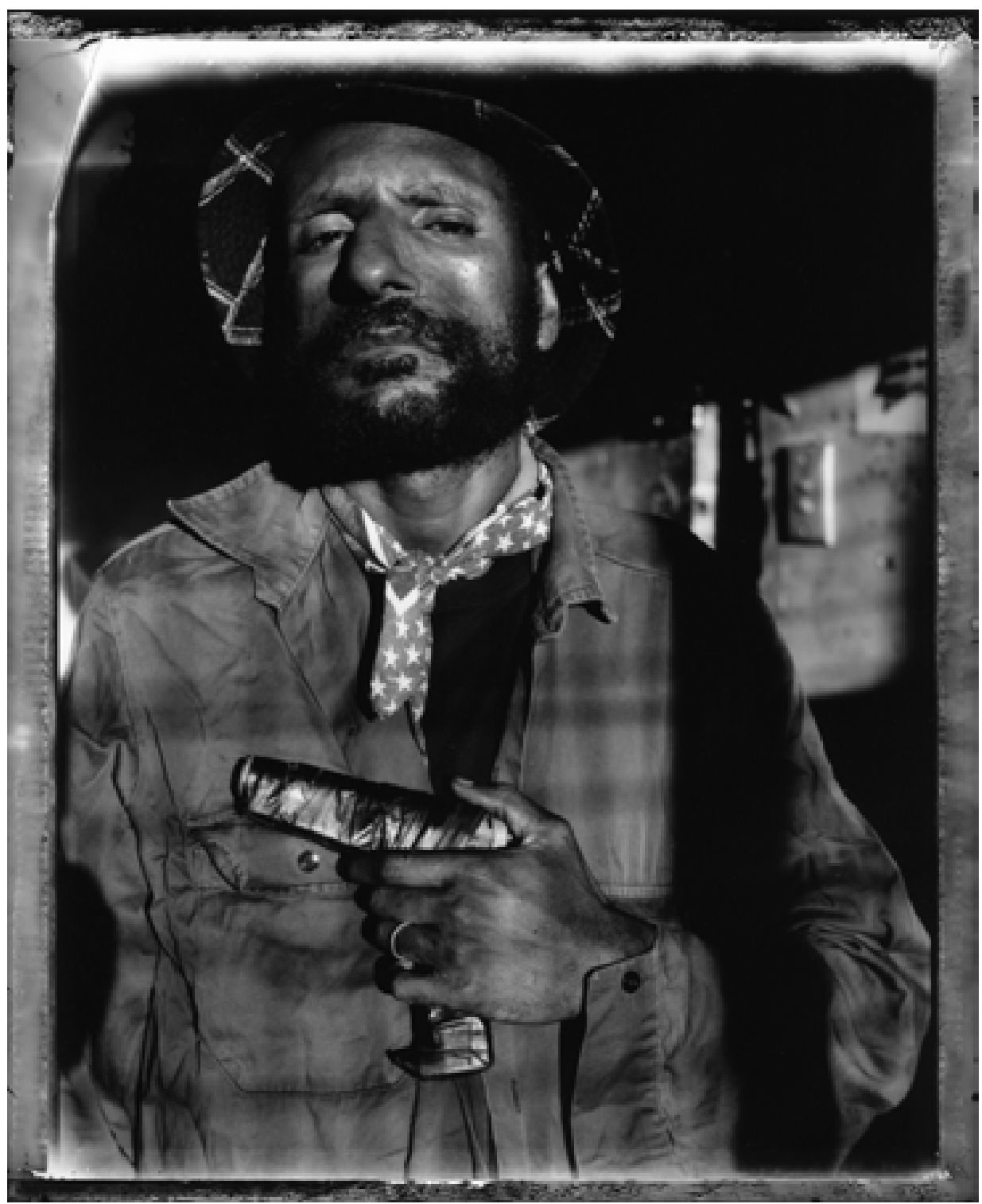

Figure 5: Portrait of Mania, from Kips Kaboni ('Red Devils'), Port Moresy, 2004. Courtesy of Stephen Dupont, www.stephendupont.com 


\section{A Composite Picture}

The great changes experienced in PNG over the last 50 years are often represented as 'shifts' from subsistence to cash; from governance on the bases of autonomous, small scale, non-literate communities to the politics and machinery of a modern state; from the moralities and worldviews fitting the one to those fitting the other. In fact, the word 'shift' is misleading, implying a universal movement in one direction.

A varied composite picture might better capture present realities. Cash has spread rapidly since the 1960s and nearly everyone has a pressing need for it, yet the subsistence economy still feeds and shelters the vast majority of the population, roughly 85 percent of which is rural (SPC 2010). While some of PNG's citizens are among the Pacific's wealthiest individuals, most languish at the low end of the Human Development Index and have limited participation in the cash economy (Bourke 2008; Baxter 2001). Also, although PNG has been an independent nation, with its laws, bureaucracy and elected representatives since 1975, for most citizens the state has little presence in their lives, government services have receded here and there, and people continue to rely (in some places even more so than formerly) on kin- and community-based governance. New worldviews, moralities and desires have been fashioned from Christian teachings, schooling, communication and interaction with worlds beyond immediate localities and via consumption, but again, opportunities for this vary while the political and moral economies that support subsistence have some kind of continuing, practical rationale for most people.

These changes nonetheless have implications for youth, beginning with the concept itself. In most bureaucratic definitions, youth is defined by numbers of years: according to global HIV policy, youth comprises persons between the ages 15 to 24 (e.g. UNAIDS ITTYP 2006); and according to PNG's National Youth Commission (NYC), youth consists of citizens aged 12 to 25 (NYC 2007). But the NYC also acknowledges cultural definitions of youth that rely on the person's attainment of social responsibilities: 'youth' is the phase after childhood but before marriage and parenthood (cf. Renkin and Hughes 2006). Older people who remain unmarried may therefore still be regarded as 'youth', and usually 'youth' lasts longer for men than women who tend to marry and have children at an earlier age. Most Pacific languages have a word for youth in the sense of young, unmarried men. In PNG, many people do not know exactly how old they are and these cultural definitions matter more.

The 'shifts' outlined above also implicate physiological and demographic effects. Some studies suggest that even small alterations in diet due to purchased foodstuffs (especially protein) have resulted in young people growing bigger 
faster than their forebears, and this probably involves an earlier onset of puberty (Jenkins 2007, 35; Worthman 1998, 29-36). Also, chiefly owing to reduced rates of infant mortality, PNG's population has more than trebled since Independence to an estimated 6.7 million (SPC 2010) and a larger proportion than previously is comprised of people aged 12-25: about 28 percent (NYC 2007, 17). The median age in PNG is 20 in contrast, say, to the European region, where it is 37 (WHO $2008,96,102)$. In more senses than one, PNG is a 'young' country.

\section{Changes Affecting the Roles and Integration of Young Men}

Changes since the onset of colonialism have affected young men with respect to their warrior function, productive and economic value, education, integration into surrounding society, and sexual relations. Colonialism arrived relatively late in PNG: from the second half of the 19th century in the lowlands, from the interwar era in the populous Highlands, and as late as the 1980s for some extremely isolated communities. Perhaps in no other nation has the colonial experience been so brief and uneven. Change has multiplied and accelerated in the last half century.

\section{The Warrior Function}

Traditionally, ${ }^{3}$ young men were essential for the defence of their communities. Before church and colonial administrations fostered peace, warfare was endemic and young men constituted every community's principal fighting force. They were largely segregated from female society, living in the men's house or accommodation for male youth and spent much time in ritual cultivation and physical readiness for war (see Herdt 1982; Herdt 1984; Jenkins 1996). Throughout PNG and the Pacific, sexual abstinence and avoidance of women were understood as necessary, at least for certain periods, to ensure masculine efficacy in warfare and other vital tasks.

Today young men, in theory, are no longer needed as warriors. Under the modern state, in principle the task of external security belongs to defence, internal

\footnotetext{
3 Tradition is a difficult term. In this chapter, it is used without inverted commas when it refers to values, practices or conditions as they existed prior to interaction with missionaries, colonial administrations or capitalist economies (even though there can still be some historical uncertainty), while 'tradition' with inverted commas is used to indicate more problematic usages. It must be stressed that traditional societies and cultures were nowhere unchanging; many practices labelled 'traditional' are recent products of creative historical processes, including processes that combine heterogeneous elements; much scholarship is very uncomfortable with habits of contrasting 'tradition' with 'modernity'; and yet, at the same time, to many people, such contrasts capture a kind of truth, or signify keenly felt change. For an entry into the huge Pacific literature and debates on tradition, Jolly and Thomas 1992 and Jolly 1992 remain classics.
} 
security to police, and intergroup warfare should no longer exist. But in PNG as elsewhere traditional values exalting warriors persist and are reinforced by icons of aggressive masculinity in popular culture (Macintyre 2008). Intergroup warfare has also re-emerged in places, returning many youths to the warrior vocation, which in turn fosters warfare. Other opportunities can be taken to express the warrior ethos too, one of them raskolism. In Stephen Dupont's photographic portraits, Koboni raskols from Port Moresby invoke both local and global symbols of the warrior ideal (Dupont 2005; cf. Macintyre 2008). In the absence of robust alternatives, some variation of the warrior appears to offer young men a ready, flexible and recognised masculine role.

\section{The Productive and Economic Value of Young Men}

Traditionally, even if their supreme value was as warriors, young men's labour was also essential for the community economy. In neo-traditional societies under colonial rule, although warfare had ceased and the warrior ethos was challenged by missions and colonial administrations (Fife 1995, 279-287), young men's productive labour continued to be valued. While young (and older) men who worked for periods on plantations were the main means for many communities of tapping the cash economy, life still largely centred on village subsistence and needs for money were few.

Today their economic and productive value has declined in several respects. Most male youth of course live rurally where their contribution to subsistence activities, if reduced, remains important, in contrast to youth in urban areas where such opportunities are scarce. But since the 1960s parents have acquired new economic expectations for their children: that they bring in money. As Barker has remarked, this expectation overlaid the economic values traditionally placed on them (Barker 1987, 98; Monsell-Davis 1998b, 317-318). The expense of school fees, particularly for boys, has often been offset against the promise of financial returns from the job that schooling would lead to. Unfortunately, jobs in the formal sector remain scanty. Only about 15 percent of men of working age have paid jobs (NSO 2003, 56) and even in urban areas more than 60 percent of adults are formally unemployed (PNG JAG 2008, 63). Also some salaried men do not pass their earnings on to their families, preferring to spend it on masculine pastimes like drinking (see, e.g. Macintyre 2008, 188-190). Michael has noted how young men in Port Moresby, whether employed or unemployed, equally drain their households (cf. Abbott 2007, 70). Large numbers of young men now probably represent a net economic cost to their families.

By striking contrast, girls and young women remain 'useful' and their economic value has appreciated. They continue to do much caring and household work, the needs for which remain relatively constant. More importantly, girls now embody 
a mighty asset that can convert into kina. In the cash economy, young women are at the peak of their market value for sex or reproductive relations. This can be leveraged by kin demanding bride-price or in a variety of other transactions (see Hammar this volume; HELP 2005). This process of commodification has been underway for several decades. More than 30 years ago Bernard Narokobi remarked: 'Parents now breed their girls like pigs in order to have them sold for a handsome price' (Narokobi et al. 1980, 130). Many families lacking daughters are keen to adopt girls for bride-price later on. As Hammar notes, terms used for a woman's vagina include her kina or goldmain (Hammar this volume; see also Hammar 2008).

\section{Education}

Education is also a vexed issue for boys. Traditionally, it was kin-based and brought benefits to the community there and then, as male youths acquired skills in, say, clearing actual land or building a real house. Now school-based learning is removed from kin and such locally useful work. Ideally, it lays foundations for modern competencies, but in practice causes many disappointments (Herdt and Leavitt 1998, 22-25).

Some problems are general. PNG has made great gains in schooling by some criteria (see, e.g. PNG 2004, 16; cf. UNDP 2009), but too many people never acquire a sound primary education. Fundamental skills in literacy and numeracy are necessary for participation in the formal economy above the lowest echelons and also for success in many areas of the informal economy. These skills also give access to a range of information and empower men and women as citizens. Yet nearly half a million people in PNG between the ages 12-25 have never been to school (NYC 2007, 18). Others have only patchy education for many reasonsschool disruptions and closures; deteriorating access due to ambient violence, decay of roads, increased transport costs; and the difficulties of paying school fees. Some data suggest that today a smaller proportion of PNG youth (combined male and female) receives formal education than in the past (NYC 2007, 18). While the 2000 census reported that literacy levels had increased to nearly 60 percent of adults, others put levels of functional literacy much lower (NSO 2003; Kidu 2008a).

But perturbing gender patterns appear. PNG's predicted failure to meet the Millennium Development Goal (MDG) of universal primary education by 2015 is often mainly attributed to barriers against girls (see, e.g. PNG 2004, 15). Yet, while families may prioritise their sons' education, Michael recalls many instances of resentment by male youths whose fees were not paid: one Papuan boy ran away, angry and ashamed, to be found six months later with strangers on a Port Moresby dump. The gap between the proportion of male youth (30.2 percent) 
who have never been to school and the corresponding female (35.7 percent) also suggests a high degree of common disadvantage. Perhaps curiously, over time male literacy has been declining while female literacy - notwithstanding genderspecific impediments to girls' schooling - has trended up. In 2000, approximately 35 percent of male youth aged 15-24 was estimated to be illiterate which was less than the female proportion; but on unchanging trajectories the proportion of illiterate male youth has been predicted to exceed female by 2010 (PNG 2004, 18). These data hint at complicated patterns of gendered disadvantage while pointing to some structural factors affecting male and female students fairly equally.

The gendered effects of post-school unemployment are grave. Less than 10,000 jobs are available for the circa 80,000 boys and girls who leave school every year, while the number of employees in industry since 1990 shows a real decline (NYC 2007, 19). No one expects job opportunities in the formal sector to suddenly, massively expand. ${ }^{4}$ Only about 5 percent of working age women have formal employment (a third of the male proportion)(NSO 2003, 56) and a de facto alternative to employment and formal education for girls is often early motherhood. Unfortunately, this can bring grief to the young women and their children, including elevated maternal and infant mortality (PNG's are the highest in the Pacific (NZPPD 2010, 29)), and hampers national development in other ways. For many young men, as Michael observes, their inability to find a job causes a particular kind of masculine pain. They are brought up with expectations that they succeed, perhaps like the 'big man' in a suit with a car, and should contribute to their kin, yet when they leave school vast numbers have no means to contribute anything (Monsell-Davis 1998b, 318-319; 2000, 218-219; cf Fife 1995, 294-296). The lack of jobs for young people is perceived by some experts and most ordinary citizens as the main driver of young women into prostitution and young men into crime (Levantis 2000, 136; HELP 2005, 14; HELP 2005, 14; PNG JAG 2008, 75).

\section{The Social Integration of Young Men}

Traditionally a web of relations, with its ideological supports, granted young men their own social space while integrating them into surrounding society and leading to full adulthood. This web is now not so tight and can be considered in terms of the 'family'. Though a fuzzy word (Monsell-Davis 1994), the 'family' is arguably the model for traditional authority structures in PNG and much of Oceania, with the senior male (more rarely female) by age, heredity or achievement as head. ${ }^{5}$ Earlier, missionary teachings and colonial administrations challenged aspects of traditional gender relations and authority (Jolly and Macintyre 1989),

\footnotetext{
4 Some analysts, who diverge profoundly in other ways, agree that the massive Exxon-Mobil liquid natural gas project, which is expected to accelerate PNG's economic growth, will create few jobs and perpetuate existing poverty (Fletcher quoted in Callick 2009; Chandy 2009, 1).

5 In some chiefly societies female chiefs could and can occupy the highest positions.
} 
but the greater challenges to local authority over the last 50 years have come from the formation of the nation state and PNG's further incorporation into global politics, economies and cultures. These processes have in some ways broached the integrity of extended family structures and weakened kin-based authority (which vice versa has often compromised state authority at local level).

One kind of weakness derives from ideological disjunction. The interests and norms of the 'family' can clash with those of other entities. In John Waiko's words, 'In ethical terms, whatever helps the group maintain itself and the land is right, and whatever goes against the group is wrong' (Waiko 1993, 235). ${ }^{6}$ At the extreme, a community may believe that killing a person accused of sorcery is just, while according to state law it is murder. A family may believe that arranging a daughter's marriage that rewards them with bride-wealth is proper, while from a human rights perspective, she is violated. A trader must make money for his business, but also share with his community (Monsell-Davis 1985; 1993b). A manager must appoint on merit but also find jobs for wantoks. As Waiko further remarks, 'Many people find it difficult to continue to identify with village society and at the same time become members of modern institutions' (Waiko 1993, 246). While creative processes of combination, transformation and continuity can be celebrated, Michael has also observed how feelings of disconnection from both 'traditional' and 'modern' worlds can significantly affect behaviour and inchoate notions of masculinity among young men (Monsell-Davis 1998a; 2000).

Traditional authority structures also indicated routes that young men could take to positions of adult influence. These routes differed, loosely speaking, across the Pacific and within PNG along the spectrum from 'big man' styles of leadership to those of the hereditary chief (Sahlins 1963). 'Big men' have been described as 'leaders of groups, coalitions and factions in pursuit of competitive ends' (Strathern 1993, 42); hereditary chiefs as descendants of gods and essential for the fertility of land, sea and people. The societies of the former are characterised as small-scale, fundamentally egalitarian for men, while comprehensively subordinating women as a class; the latter as hierarchical and often on a larger scale, in which principles of heredity, seniority and female descent create complex relations of status whereby women can sometimes outrank men. In practice a range of leadership styles combining varying degrees of achievement and heredity manifested throughout the Pacific region and in PNG too where, as Herdt and Leavitt (1998, 16; cf. McLeod 208) observe, the ranking systems of Trobriand culture differ significantly from the 'big man' politics of the Highlands. Yet 'big man' styles have tended to predominate in PNG. Whereas the path to status in hierarchical societies was often through reverential service, in PNG young men built up their

6 For a searching discussion of 'justice' from the vantages of state law and local socialities, see Goddard 2009. 
own influence and networks and so in time could openly challenge dominant men. Women's productive and reproductive work supported men in their pursuit of renown - unmarried men would get nowhere.

Because 'big man' leadership styles lend themselves to continual challenge, this kind of leadership, in changing conditions, may be so fluid and aggressive that a stable ethical environment for integrating male youth is lacking. In some communities, older men now feel powerless in the face of aggressive young men, often with guns (e.g. Dinnen and Thompson 2009; cf. Haley this volume). In some circumstances the violent and wayward behaviour of male youth has been explained as their seeking the traditional status of older men, but, with the waning of traditional institutions, having to beat modern pathways to it. Some researchers have broadly interpreted raskolism in this way (Goddard 2005; Dinnen 2001; cf. Leavitt 1998).

The 'family' has also been changing. The change commonly remarked is the supposed 'shift' from the rural extended family to the urban nuclear family. In fact, a complex series of urban and rural changes has been underway. In the past the extended family was of central importance throughout Oceania. It formed a labour pool (cf. Finney 1973). All members contributed in various ways to household and community welfare and each faced sanctions if he or she failed to fulfill reciprocal obligations (cf. Belshaw 1964, 21). This arrangement is still vital for the subsistence activities on which most PNG citizens depend. Nevertheless there is evidence in rural areas of a trend towards the nuclear household, particularly in day-to-day affairs (Monsell-Davis 2005; cf. Finney 1973; Kay 1971; Hezel 2001). This is partly in response to Christian emphases on the nuclear family, but increasingly to the greater use of cash.

In urban areas extended families are somewhat different. Government authority housing was built with the nuclear family in mind, but numerous accretions are common, as children of the original couple raise their own families under the same roof (cf. Pantumari and Bamne this volume) or relatives come to stay. And many people crowd into settlement dwellings. Urban households thus tend to be larger on average than their rural counterparts, even if couples have fewer children. ${ }^{7}$ They also frequently contain members who are less closely related and often centre on a woman as its stable core (cf. Kay 1971). As someone said to Michael, 'in town the woman is boss!' - and the relatives who come to stay are frequently hers. An elderly man in a village outside Port Moresby added 'Why do you think I never go to my son's house in town? It is always crowded with his wife's relatives'.

7 The national average is 5.4 persons per household (NSO 2003, 70), but recent surveys found 9.6 in Port Moresby, 8.8 in Lae and 8.3 in Mt Hagen (PNG JAG 2008, 62, 63). 
The commitment of household members to household welfare is often less uniform in urban centres too. First, unemployed members may be unable to constructively contribute; and second, even where several members are salaried, it is not uncommon to find them spending money on their own interests. This can be especially true of young men who want to drink and party and purchase personal property. Disputes arise from overcrowding, failure to contribute, and conflict over resources. Michael recalls married brothers and sisters in Port Moresby hiding food from each other's families, outbursts of domestic violence, and young people leaving to seek refuge with other kin or friends. Increasing numbers of children and young people live together in shacks, drains or on the streets (Buchanan-Aruwafu et al. 2002,8).

In urban communities that are not physically and socially so tightly bounded, collective opinion and authority can be harder to shape and enforce. While many people live in settlements ${ }^{8}$ surrounded by wantoks, ethnically mixed areas are increasing and it is common to hear about difficulties caused by 'outsiders' (see, e.g. James et al. 2009, 25); the number of individuals whose parents come from different areas or whose first language is Tok Pisin is also increasing (Goddard 2005, 7; HELP 2005, 15-16); the range and coverage of community institutions, such as churches, peace committees, village courts and youth groups vary, and the abilities of communities to handle internal difficulties through kin mechanisms or such institutions vary too (James et al. 2009, 17-62). This variation in social bonds and the structures of local urban authority (whether rooted in kin, state, church or business) results in gaps and weaknesses that hamper the regulation and integration of young men. Some forms of raskolism are arguably, in part, one symptom of these difficulties. ${ }^{9}$ So is the private security industry, a major source of formal urban employment for young men within the limited number of jobs on offer.

\section{Sexual Relations}

Finally, how has change affected young men and sexual relations? Contemporary sexual practices involve great tensions and confusing trends. It may be helpful initially to consider, very broadly, the role of sex in subsistence and cash economies as they coexist and interact in PNG.

PNG's traditional sexual cultures have been said to range from 'sex positive' to 'sex negative'. The former are described as celebrating sexuality (especially

\footnotetext{
8 A settlement strictly speaking refers to an unplanned residential area, in contrast to a government-planned suburb. 'Settlement' is used more loosely in this chapter to refer to urban residential areas where many poor and ordinary people live.

9 This line is consistent with the 'culturalist' interpretations of raskolism by Goddard (2005) and Dinnen (2001), which stress how raskol activities can represent an adaptation of traditional politics and economics to modern conditions.
} 
youthful sexuality), often correlate with political styles that favour principles of hereditary rank (which in turn tend to accommodate more complex articulations of female status by descent) and seem to grant a lesser role for gender and sexual violence - the Trobriands for instance have often been depicted in such terms (Malinowski 1929; Lepani 2007). 'Sex negative' cultures are said to stress the dangers of sex, particularly to male potency; to correlate with a masculine politics of egalitarianism and open competition (predicated on the subordination of women and entailing a certain 'sex antagonism'), and to grant a greater role for gender and sexual violence - some traditional sexual cultures of the Highlands are often so described (Zimmer-Tamakoshi 1997; Meggitt 1964). Of course, these are caricatures, but perhaps indicate some dimensions of traditional difference in the big picture.

Commonalities however are more important. Traditional cultures in PNG and throughout Oceania fundamentally valued fertility and reproductive efficacy, in people and their environment. These were preconditions for survival and social generation - and human sexuality and the children it produced were, among other things, economic and political assets. The collectivity had vested interests in managing the reproductive potential of young people that, in important senses, 'belonged' to their clan or line. Even cultures that allowed young people latitude for (usually clandestine) sexual liaisons circumscribed youthful sexuality in various ways. Another widespread assumption-found beyond Oceania too-held men's sexual urges to be almost impossible to control from within. Spatial segregation of the sexes and social mores governing interaction between them were important forms of sexual regulation.

The sexual cultures linked with the cash economy in PNG implicate, by contrast, some globalised ideologies that value individualism, choice, mobility and consumerism. ${ }^{10}$ In some strands of thought, reproduction is not necessarily a central sexual value, even for heterosexual activity (and indeed, children can represent considerable costs in many cash economies); sexuality is in important senses the rightful property of the individual and a medium through which individuality can be realised; and people are expected to manage their sexual desires in their interactions with others and in the various mundane social spaces where different genders mix.

10 For a broad treatment of this theme, see Altman 2001. 
In Papua New Guinea, these broadly contrasting economies, with some of their implications and ideological supports, overlap in the lives and consciousness of many people as depicted so evocatively by contemporary Papua New Guinean artists (see Figure 6). ${ }^{11}$ The gendered cartography of everyday life was already being redrawn under colonialism, as new principles for the Christian family were enjoined and new social spaces created by administrative and money-making activities. But these processes have enlarged over the last 50 years, and the kinds of places and activities that throw people together who would have traditionally had fewer or no opportunities for contact, including sexual contact, have proliferated. Sexual values, rooted in very different sexual economies, can mingle in the same social zones, hybridise, and adapt to the opportunities offered by the other.

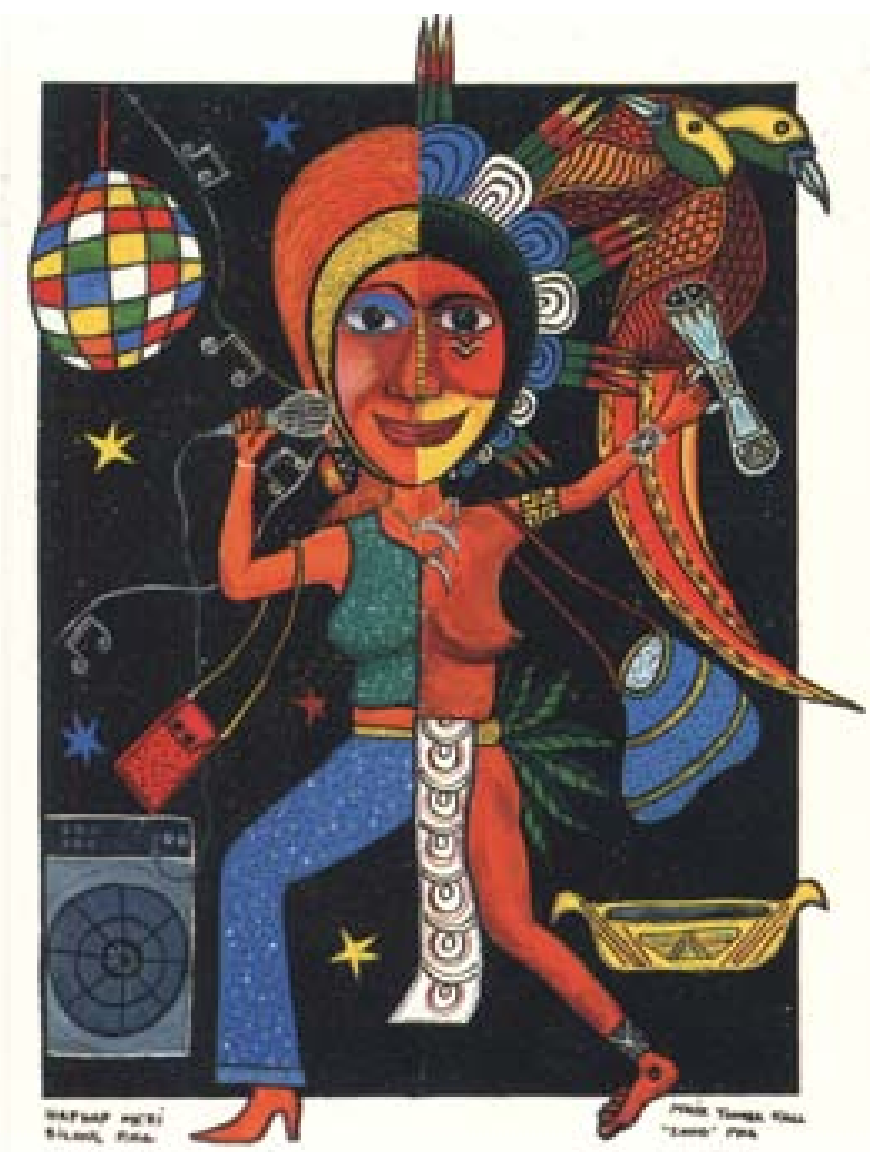

Figure 6: Haphap Meri bilong PNG. By Maik Yomba Kagi, 2000. www. Pazifik-Infostelle.org

11 Another splendid graphic representation of this overlap is the painting Boi pren na girl pren. Tupelo lusim tingting long pasin bilong wait man (Boyfriend and girlfriend. They no longer think about their local customs and instead have taken the customs of the Europeans) by John Siune, 1999, from Clive Moore Private Collection, but reproduced on the dustcover of Moore 2003. 
Much attention has focused on women in this interaction, particularly concerning the multivalent commodification of female sexuality. Kin manage some modes of this commodification along loose analogies with the traditional management of female sexual and reproductive assets. Financial demands by kin for bride-price and the like are arguably adaptations of the traditional economy to the cash economy, and similar explanations can be offered for compensation claims and acquisitive raskolism (cf. Goddard 2005; Dinnen 2001).

Other modes of commodification, exercised by the woman herself, reveal a range of possible motivations. Sometimes a woman's resort to 'sex work' is retaliation against immediate family. Holly Wardlow's work among Huli pasindia meri (women who travel around and sell sex) found that for many this was primarily a way of 'getting back' at kin who had failed in their responsibilities: the woman was therefore denying them what was theirs - her sexuality and its economic returns (Wardlow 2006, 134-165). For other women, sex work can be a means to economic autonomy and the exploration of possibilities that would otherwise be closed to them (such as the young girl who explained that she wanted to be a prostitute 'and get feelings. Get feelings like happiness' (Jenkins 2007, 45)). But for most, sex work seems a brute financial necessity: whether housewives, sisters or daughters needing to feed their families; school girls seeking money to pay school fees; university students needing cash for soap and tampons; or uneducated, abused women, alienated from subsistence supports, without other means for survival.

Many PNG women (see, e.g. Garap 2000; Kewa 2007) believe that women and girls are now more vulnerable to abuse than before. The commodification of female sexuality has in many circumstances enabled men to hurt girls and women with untraditional immunity. Wives can be mistreated as bought objects (Kewa 2007, 46-49). A sexually abused child may be paid afterward by her abuser, retrospectively 'regularising' the act as a transaction (HELP 2005, 43, 45). Compensation to kin for a daughter's rape does little to repair the damage to her and sometimes offers the offender a way of avoiding a severer traditional penalty, such as death (e.g. Banks 2000, 92). Money also gives a few men a fast track to status and a scale of prerogatives that would be harder to earn and exercise traditionally, including a much greater capacity to buy sex, women and wives. Clement Malau has observed that the modern cashed-up 'big man' is removed from former restraints and the obligations of traditional polygamy (Malau quoted in Guy and Crofts 2000).

On the other hand, the degree of independence and affluence that some young women may derive from sex with moneyed men can anger other men, particularly those without money, and prompt a punitive response. Other women totally dependent on selling sex earn very little and lack any measure of safety that may be offered by kin. In the absence of state or other protection, such women 
can be mistreated with impunity. Several cases in this volume describe abused women who evidently had no kin who could or would effectively assist (Luker and Dinnen introduction this volume; Haley this volume; Luker conclusion this volume). Many women routinely raped by police appear to be in this predicament (Jenkins this volume).

Two key points about young men can be stressed. First, several factors seem to favour their involvement in rape-and a high proportion of male youth state that they have used force to have sex: for example, 49.3 percent of unmarried, 61.4 percent of married young men in one sample (Millan et al. 2006, 42). Some offer an economic explanation. Most male youth have difficulty 'buying' sex, as discussed above, and their sexual rebuff or exclusion on the perceived grounds of pennilessness can cause resentment that, in Michael's experience, not infrequently leads to rape. Similarly, Jenkins and Alpers found that many young men 'justified rape on the grounds that they could not compete financially for sex. Therefore, whenever an opportunity arose ... it had to be acted upon' (Jenkins and Alpers 1996, 248; cf. Banks 2000, 93; 98-100). Rape in this sense is analogous to theft, and seems often understood as such (Jenkins 2007,60). Thus the theft, robbery and rape committed by raskols, that researchers tend to put in two different boxes (one marked 'property crime', the other 'sexual violence') can be considered in some contexts within the same frame as economic acts.

A cultural consensus around rape that might offer young men (and everyone else) consistent guidelines is wanting. Certain sexual acts that state law defines as rape are 'traditionally' accepted in many cultures: such as rape for punishment, in war, as 'payback', of women who don't count, or because circumstances permit. Indeed, a concept and term for rape is absent from many PNG vernaculars (Strathern 1975; Borrey 2000; Banks 2000). Researchers have also noted that where ordinary sex resembles rape, one can be hard to distinguish from the other (e.g., Borrey 2000, 107). For many men and women, rape within marriage is normal too, tallies with beliefs about uncontrollable male desire, and is further justified in modern understandings (at odds with equally modern concepts of human rights) that bride-price entitles husbands to treat wives as purchased property (cf. Eves this volume; Macleod and Macintyre this volume). While one must emphasise that rape has little traditional precedent in parts of PNG (Zimmer-Tamakoshi 1997, 539; Lepani 2007) and the nation's progress towards addressing violence against women has been described as now 'on a strong upswing' (Ellsberg et al. 2008, 120), contemporary values and ideas concerning rape could still be described as 'pluralistic'. As Hukula has noted, an act of rape can occur simultaneously in several different social realities (Hukula 2005, 14).

The same general remarks for rape apply specifically to lainap, which, though pack rape happens all over the world, seems unusually prevalent in PNG. A national survey in the early 1990s found that 60 percent of male informants had 
participated in lainap (NSRRT 1994, 102); countless reports testify to routine occurrences in town and village (Jenkins 2007, 62); and the practice appears normal within some masculine occupations (see, e.g. Pantumari and Bamne this volume; Jenkins this volume; McLeod and Macintyre this volume). Jenkins has argued that lainap expresses intense masculine homosociality traditional in many PNG societies that persists into the present (Jenkins 1996). Occurrences traditionally related to men's house and warfare provide seeming precedents both for its practice within the army and police today (see Jenkins this volume; McLeod and Macintyre this volume; Pantumari and Bamne this volume). ${ }^{12}$ Traditionally, pack rape may often have been a young warrior's sexual initiation, and older men can use lainap today as a way of rewarding younger men and introducing them to sex (NSRRT 1994, 104; Jenkins 1996 203-204; Hukula 2005; cf. Pantumari and Bamne this volume). Common forms of raskolism accommodate these features: by invoking the warrior ideal, taking rape for granted as an intrinsic activity (raskols who dislike rape seem exceptional (e.g., Goddard 2005, 103-104; Werf 2009, 89)), and using lainap for these purposes.

Secondly, young men - and women - are caught up in wider, diffuse changes of sexual mores not captured in the spotlight here on certain types of commodified sexual relationships or on rape. While sexual values prizing reproduction, the family, and community still have a strong basis in subsistence economies and in church teachings, generally a certain relaxation of earlier cultural constraints have been noted (but see Jenkins 1996, 193-194). For instance, in the villages on the central Papuan coast where Michael has worked, a boy's sexual adventures were once curbed by the crucial need for sometimes lengthy sexual abstinences as ritual preparation for warfare, trading expeditions, competitive dancing or canoe racing, and to a lesser extent before hunting or fishing and continued to be practised for special undertakings. Such restrictions have eased significantly over the last 40 years. Certain research also sees several modern factors strengthening the formation of a gender inclusive 'youth culture', that is, a 'horizontal' social entity meshing young men and women according to age in contrast to youth divided 'vertically' by kin or gender (Herdt and Leavitt 1998). Schooling is a major factor in this; so is identification with symbols of local or global youth culture that become markers of that cohort's identity; and also are other shared activities, which may involve sexual intimacy and relatively recent patterns of consumption (such as drinking alcohol, smoking marijuana, viewing videos and DVDs). These changes contribute importantly to portrayals of youth - as unemployed, inadequately educated, suffering family breakdown, abusing substances, watching pornography, engaging multiple sexual partners, alienated

12 It should be noted, however, that 'traditional precedents' are not necessarily explanations. 
from community, and lacking access to public goods - in which juvenile crime and the risk of HIV to youth also figure (e.g. Sikani 1997; Buchanan-Aruwafu et al. 2002; HELP 2005; Jenkins 2007).

Such dystopic visions tend to have an urban setting, but need not be confined to town. Poverty is entrenched in some rural areas; the imbalances between enclave capitalism and economies heavily dependent on subsistence can cause huge distortions for affected communities; while generally, rural PNG has suffered most from retreating services, deteriorating infrastructure, and neglect-and remains of course sensitive to natural hazards (Baxter 2001; Bourke 2008; Ninkama 2009). A Papuan community that Michael has known for decades had experienced several years of increasing poverty on his last visit (MonsellDavis 2005): crayfish - the principal money-earning resource - were gone, and a long drought combined with poor soil had killed the gardens. Anxieties about sickness were rife, and sorcery accusations appeared to be on the rise. People were also troubled by the withdrawal of chiefs from village leadership, how once cooperating households were now behaving independently, and by raskols and 'law and order'. In contrast to the early years of Independence (Monsell-Davis 1987), their own male youth were causing problems too. Sexual activity among young people was also perceived to have increased and teenage pregnancies from casual liaisons seemed more common.

Nicole Haley provides another example. Around Lake Kopiago, in the Southern Highlands Province, an elderly informant shared songs that he had once sung with fellow youths to celebrate their land and their own splendor. This age-group had reached adulthood before 1955, after which colonial rule began extending, indigenous ritual activity died away, and the bachelor cult was abandoned (Haley 2008, 220). By sad contrast, today's songs reflect the 'untraditional' gun and gender violence now pervasive, and the poor estimation young men have of themselves, their ground, their competence: 'impoverished with nothing to offer'. The words of a 2002 election chant translate as 'Kopiago, truly the last place development occurs' (Haley 2008, 222, 225; cf. Haley this volume).

These evocations of maldevelopment, which frame negative depictions of youth, challenge common tendencies among many Papua New Guineans and outside observers to idealise the village as opposed to town (Zimmer-Tamakoshi 1990) when in practice, a line between rural and urban life is often hard to draw. Other caveats are worth noting. Although rural maldevelopment can be acute and rural poverty hidden from view, subsistence still manages to support most citizens on their land with kin; while hardships in town are prone to grim stereotype, they can mask the more complex realities of settlement existence (Goddard 2005, 2-8). As Allen observes, the 'youth problem' is nothing new (Allen 1987, 33, 36-39; Barker 1987) and in cultures that allowed for dominant men to be openly challenged, young men have perhaps always been a source 
of disturbance especially during times of stress. Finally, against lurid pictures of today's youth, some research throws up countervailing data: for instance, a generally later age of sexual debut and fewer sexual partners in some sampled populations than darker depictions of sexual mores might suggest; a relatively small number of girls in a high-risk setting selling sex; the appeal to young people of quite 'traditional' sexual and reproductive aspirations; and the continuing support and integration provided by structures of kin (e.g. SivusiaJoyce 2004, 10-11, 14; Naemon 2009, 93; Kelly et al. 2008, 10; NCY 2007, 12).

\section{Teasing out the Tangle}

The tangle of associations that link young men, raskols, property crime, rape, youth HIV nonetheless seem to emerge naturally from these visions of maldevelopment, but its elements can be usefully teased out, reassessed and perhaps repositioned in both the response and the rhetoric relating to HIV and 'law and order' in PNG.

First, raskols, as already indicated, are not all young men. Some labelled as such are younger or much older (see, e.g., portraits in Dupont 2005). There is also a difference between youths who play to the raskol image without strong criminal commitment or experience and the raskols in Goddard's and Dinnen's influential studies (Goddard 2005; Dinnen 2001). They were older or married with children, in some cases even educated men who once had enviable jobs, but had become accomplished criminals committed to the raskol road.

Second, property crime broadly defined ${ }^{13}$ and rape cannot be reduced to raskolism in the original scope of the term. Rape, as discussed above, covers sexual coercion in a range of contexts by a range of perpetrators. The special media and women's anxiety over rape by raskols may owe partly to its ability to evoke a sense of urban anomie and indiscriminate vulnerability (cf. Borrey 2000; PNG JAG 2008). The character of raskol collectivities has also evolvedto encompass very loose gatherings, tighter networks, and integration within formalised business structures - and this reflects a range of property crime too: from 'low end' opportunistic and street crime, to 'high end' heists and organised commercial enterprises that can involve leading politicians, businessmen and international players (Harris 1988; Goddard 2005; Dinnen 2001; Levantis 2000; Bashir 2009). The youthful face of raskolism, with its persisting connotations of the low end, does not capture this spectrum. Nor does it invoke 'white collar' crime and corruption, with their frequent accomplice, mismanagement.

13 Property crime is broadly defined here to include theft and robbery (that is stealing both with and without force); and also 'white collar' crime and corruption. 
However, raskolism in its original connotations of theft and robbery may represent the kinds of crime people are most likely to have personally suffered (PNG JAG 2008, 14-40).

Yet 'high end' activities, 'white collar' crime, corruption and mismanagement pose huge challenges for both PNG's governance of security (see, e.g. INA 2004) and experience of HIV. Respecting the latter, the possible effects on HIV's spread from criminal enterprises - in particularly narcotics or sex-are known from other countries, but perhaps more pertinent is the role of corruption and mismanagement in weakening PNG's government response. Thus, for instance, though mothers' needs for antiretroviral prophylaxis are largely unmet and increasing, the number of women who received it dropped when these services were transferred from church to government health services (NACS and Partners 2008, 42). The Department of Health failed to distribute millions of condoms that consequently passed their use-by date (Joku 2009). The National AIDS Council was suspended and restructuring commenced in response to, among other concerns, a scandal involving millions of kina (Nalu 2009). Corruption and mismanagement were considerations in the 2009 decision of the Global Fund not to renew assistance to PNG that, inter alia, funded antiretroviral treatment (ART) for 7000 Papua New Guineans (Fox 2009). Cessation of drugs would not only kill these patients, but jeopardise ART as a pillar of the national response.

Third, the contribution of rape to HIV transmission must be seen in the broader context. In much expert literature, rape figures as a major spreader of HIV. Transmission from male rapists to female victims is highlighted with stress also on rape of women by their husbands and regular partners (cf. Eves this volume; Hammar this volume). The dangers of infection to female rape victims are not just due to their difficulties negotiating condom use (Lewis 2009): because the vaginal male-to-female route for HIV is so much more effective than femaleto-male (Whiteside 2008, 30), because rape often involves vaginal abrasion and injury that increases the chances of female infection, and because young rape victims are more attractive targets and their immature vaginal lining is more susceptible, HIV is a grave risk from rape for women, particularly young women. And this risk is very widely experienced (see, e.g. Lewis 2009).

Rape, specifically lainap, does however pose a particular HIV risk to men, and perhaps to young men. This is tricky to discuss, because the information may be taken to confirm beliefs that women cause infection; to support tendencies, reflected in newspaper accounts (see, e.g. Luker this volume conclusion; Anon. 1994; 1998), to sympathise with rapists; and to condone rape so long as condoms are used (cf. McLeod and Macintyre this volume; HELP 2005, 21) Yet, as Jenkins has stressed, much greater than the risk of contracting HIV from any woman they rape is men's risk of contracting HIV in lainap by making contact in the woman's vagina with infected fluid from another man in the line (Jenkins 
1996, 204). While the likelihood of an uninfected woman receiving HIV in such circumstances is even higher, a larger number of men can be exposed to elevated risk in a single act of lainap (Jenkins 1996, 204; NSRRT 1994, 105). Perhaps in toto more men than women contract HIV through lainap and if some male youth are more likely to participate in lainap than in other modes of sexual intercourse, this practice could represent a proportionately higher risk of HIV to young men.

But overall, is rape a major driver of HIV's spread in PNG? Some researchers (Barnett 2008, 8; cf. Epstein 2007, 245-246) have suggested that in countries with high levels of heterosexually transmitted HIV, rape and intimate partner violence may prove ultimately less important than transactional sex, which as Hammar (this volume) demonstrates, can encompass very diverse relationships beyond strict definitions of sex work. For epidemics mainly reliant on sexual transmission, Epstein and others also suggest that the nature of an unprotected sexual act perhaps matters less in the wider frame of reference than the character of the sexual network in which it occurs: to reach high prevalence, HIV requires far-reaching concatenations of concurrent sexual relations (as distinct from strings of serial multi-partnering), whereby a significant proportion of both men and women have more than one regular sexual partner at the same time (Epstein 2007, 54-95). The implications of these theses require more thought in regard to $\mathrm{PNG}$.

The role of young men in the spread of HIV in PNG requires more thought too. Assessing their involvement is hampered by the fact that young men are the least likely of any adult group between the ages 15-45 to be tested. More is known about their female counterparts through young mothers at antenatal clinics. Yet available statistics suggest that HIV levels for young men in PNG are relatively low, even allowing for under-reporting. Those aged 15-19 account for the fewest HIV infections detected for any sex-specific adult cohort under the age of 45; and the total for young men 20-24 is relatively low too. The biggest contrast is between these figures for young men and those for girls and women of the same age, which are extremely high (CAP 2009, 29). This discrepancy between female and male youth is found in other countries with generalised prevalence of heterosexually transmitted HIV (Monasch and Mahy 2006, 23).

For global HIV policy, youth has been central to prevention (Monasch and Mahy 2006). As Buchanan-Aruwafu notes, this category cuts across groups identified to be at higher risk of HIV: men who have sex with men (MSM); those involved in injecting drug use (IDU); and sex workers and their clients. Young people may also facilitate the wider spread of HIV by moving between different sexual networks and risk-settings (Buchanan-Aruwafu 2007, 82-83). Social mapping 
in PNG has identified some localities, such as the settlements of Hanuabada and Joyce Bay in Port Moresby, where youth intersects with more than one of these higher risk groups (Millan et al. 2006, 17, 38-55; NHASP 2006, 59-62).

How do young men in PNG fit into this generic framework? IDU is negligible in PNG, though tattooing, scarification and penile modification can carry some risk of HIV transmission (Buchanan-Aruwafu et al. 2002, 8, 12; cf. Law this volume). The MSM factor and its epidemiological significance are difficult to ascertain. Although the ritual homosexuality practised in a handful of PNG societies has passed (Jenkins 1996), sex between men occurs in institutions such as prisons (see Law this volume); sometimes between men in lainap (NSRRT 1994, 105); in male to male sex work (Jenkins 1996, 196; Buchanan-Aruwafu et al. 2002, 9; HELP 2005, 61-62); and nearly 12 percent of young men in one survey reported having had sex with another male (SCiPNG 2008, 22). Because men, including young men, who have sex with men usually also have heterosexual relations (Jenkins 1996; Buchanan-Aruwafu et al. 2002, 9) and very few socially identify by an exclusive homosexual preference (e.g., NHASP 2006, 59; Engels 2008, 9), the MSM factor is camouflaged. Nevertheless the predominantly heterosexual dynamic of transmission in PNG seems both pronounced and corroborated by molecular epidemiology. ${ }^{14}$ Finally, how do young men participate in the risk category of commercial sex workers and their clients? Aside from some youths engaging in homosexual sex work and scanty evidence of transactional sex with older women (Millan et al. 2006, 43), young men appear primarily excluded from one of the major epidemiological flows of HIV in PNG: from older men with 'purchasing power' to younger women with sexual goods.

Within this generic framework, the risks of HIV to young men seem much smaller than to young women, and the role in HIV transmission played by older men of more concern than by younger men. As Kalichman observes, whether dealing with heterosexually or homosexually transmitted HIV, in general 'Older men are more likely to have HIV, resist condom use, and have sex with multiple younger partners' (Kalichman 2009, 125). The dakglas kar man (dark glass car man), as Lepani remarks, is the pisin equivalent of the sub-Saharan 'sugar daddy' stereotype, and evokes 'the businessman, politician or landowner with plenty of disposable income who drives a car with tinted windows' (Lepani 2008, 152). The travesties and dangers of the dakglas kar man stereotype are of less interest here than the fact that, despite perhaps the odd allusion in local media (e.g. Muri 2009; Anon. 2004) very little public concern attaches to it, in contrast to the widespread blame of 'prostitutes' as sources of infection (see especially Fletcher and Gonapa this volume; Stewart this volume) and explicit anxieties about the sexual predations of young raskols. Certainly the moneyed older man can be

14 The predominant subtype of HIV in PNG is most closely related to East African strains (CAP 2009, 22) and correlated with heterosexual transmission. 
difficult to challenge - a point David Lornie has made well with the character of Dennis in his HIV novel, Vavine's Curse, set in Port Moresby (Lornie 2008). PNG is not alone however in tending to focus away from older men and generally from people aged over 25. UNAIDS has observed that internationally 'relatively few prevention programmes have specifically focused on older adults' (UNAIDS $2009,9)$. Older men are arguably a greater challenge than young men in relation to HIV and probably ditto in relation to crime.

\section{Conclusion: A Chance Encounter}

These observations upon teasing out the raskol tangle perhaps highlight some other angles on masculinity, youth, crime, sex, and HIV that also need bringing into focus. But they do not negate the need for responding to the plight of youth, female and male, or specifically reducing the involvement of young men in property crime and rape, or minimising the exposure of all youth, and particularly young women, to HIV. This is not the place to review many measures and proposals that currently target young people. ${ }^{15}$ Instead, we would like to finish with a story and reflections on three of its themes.

Carol Kidu's autobiography recalls a chance encounter. In 1997 she was running for parliament on an 'intellectual campaign' that would explain her policy platform and background. She knew she would need to use pictures, because many languages were spoken in her Port Moresby electorate and illiteracy levels were high. With the help of an unemployed artist and sheets of plastic donated by a local business, she used charts to cover such questions as 'What is the work of a politician?', 'What is the power of your vote?', 'How does a budget work?', and 'What is development all about?'

I will always remember well one incident. I had completed an educational campaign in a very poor settlement, notorious for its law and order problems. As usual a few young men hung around in the shadows of the trees listening to me. I encouraged them to join the other people in the small audience, but they did not do so.

15 Renewed efforts have been taken to involve young men in sport and community policing (NYC 2007, 3; PNG 2007, 35). Youth groups have proliferated, and The National Youth Policy observes that those including older members and tied into kin structures tend to endure. (NYC 2007, 3). A range of initiatives have been taken by the NAC, churches, universities, schools and others to equip youth to deal with HIV (NYC 2007, 3132). Alongside expanded formal schooling and tertiary education, Kidu has advanced the idea of community centres that would serve as hubs for information, referral and life-long learning for the benefit of all, including disadvantaged youth (Kidu 2008a, 2008b). While no one expects a swift expansion of formal employment for young people, some see in the informal sector scope to increase opportunities for legitimate cash livelihoods (Levantis 2000, 141; NYC 2007, 31-32). 
Unexpectedly, one of the young men came over to me when I was leaving, and looked into my eyes and simply said, 'Thanks for giving me hope.'

In him I saw the skinny, hollow-eyed look of poverty with his pants slipping below non-existent buttocks. But beyond those hollow eyes was a young man with dreams - unattainable dreams. There was a softness in his voice that betrayed his attempt to look like the gang and portrayed a gentleness that did not match the gang image. As soon as he had spoken, he slipped back into the small crowd of people to disappear forever (Kidu 2002, 155-6).

This young man might have passed as a raskol. He was a child of Independence: perhaps a few years younger, probably no older, than the nation of Papua New Guinea. The talk he listened to explained basic relationships between government, citizen and development. These are the themes for our final reflections.

First, citizen: while this was the young man's official status, in some senses it was unreal. The concept of citizenship, implicated in the notion of civic security central to this volume, has been discussed in youth studies since the 1990s (e.g. France 1998; Helve and Wallace 2001) with respect to rights, duties, responsibilities, participation and access to society's institutions. But as Sister John-Paul Chao reflected 20 years ago, on a settlement nine miles from Port Moresby's central business district - where many households lacked adequate food for days at a time; had no money to obtain medical help or to catch buses; were repeatedly searched by police without warrants; failed to enrol their children in school; in other words, resembled many households today - there is a 'hopeless gap' between people's aspirations and realities. 'Until they stop standing on the periphery... citizenship will remain an empty word devoid of meaning. If there is no participation, [there can be] no real sense of citizenship' (Chao 1989, 104) - and, one might add, an accompanying sense of responsibility to wider society.

Second, government: although Kidu's interlocutor lived in the capital, close to the central institutions of national politics and bureaucracy, this encounter between a candidate and a voter suggests a gulf between the worlds of state and local life that is even wider in most parts of the country. While some commentators stress the separation between the political elite and ground-level settlements and villages, unfortunately government institutions connecting these worlds have in many places weakened or receded during this young man's lifetime. As many recognise, and this book also stresses (see Luker and Dinnen this volume chapter one; Luker this volume conclusion), institutions in this connecting zone, and their infrastructure, need strengthening-some have argued in terms of hubs (Kidu 2008a; 2008b; Anon. 2008), a reconstrued kiap 
model (Dinnen and Braithwaite 2009), cross-sectoral partnerships (HaywardJones 2008), generalised systemic reform and, as advanced in this volume, 'whole of governance' approaches (Luker and Dinnen this volume, chapter one and Luker this volume, conclusion). The people who work in this zone-teachers, police, health workers, agricultural personnel, alongside workers in churches and nongovernment sectors - need fostering. They have a special potential for cultivating public goods, providing constancy, assisting community energy and initiative, and supporting processes of local understanding and innovation. Problems facing communities, including lawlessness and such challenges as HIV, must be understood in the wider context and longer term of very broad change, looking back and to the future (cf. Reid this volume, ch. 13).

Finally, development: what is it? Carol Kidu's presentation and the hope it kindled in the young man suggests that he understood development as something closely bundled with government and politics. And perhaps among his dreams was a hope for a livelihood. The lack of economic opportunity haunts the condition of young people today discussed in this chapter, but goes beyond raskolism and HIV. As Abbott remarks, youth unemployment, however we define it, is one of the most critical issues for governments of the Pacific region (Abbott 2007, 69) and for the hopes of people, young and old, rural and urban, that their efforts will sustain a future for themselves and their families.

\section{References}

Abbott, David F. 2007. Poverty and Pro-poor Policies for Pacific Island Countries. Asia-Pacific Population Journal 22 (3): 59-74.

Allen, Bryant. 1986. Five Generations of Youth at Dreikir. In Youth and Society: Perspectives from Papua New Guinea, ed. Maev O'Collins, 33-42. Canberra: Department of Political and Social Change, Australian National University.

Altman, Dennis. 2001. Global Sex. Crows Nest, NSW: Allen and Unwin.

Anon. 1994. Compensation for Who? Pacific AIDS Alert Bulletin, 8, 13.

Anon. 1998. Rapists warned of AIDS Risk. Pacific AIDS Alert Bulletin, 15, 11.

Anon. 2008. Kidu Opts for New PNG Community Policy. Radio New Zealand International, 18 March 2008.

Anon. 2004. Shocking News. Post-Courier, 29 September 2009. 
Banks, 2000. Contextualising Sexual Violence: Rape and Carnal Knowledge in Papua New Guinea. In Reflections on Violence in Melanesia, ed. Sinclair Dinnen and Allison Ley, 83-104. Annandale: Hawkins Press and Canberra: Asia Pacific Press.

Barker, John. 1986. In Youth and Society: Perspectives from Papua New Guinea, ed. Maev O'Collins, 81-108. Canberra: Department of Political and Social Change, Australian National University.

Barnett, Tony. 2008. Hoping or Discounting the Future: A New Perspective on the Transmission of HIV/AIDS. WDP 2008/8. Helsinki: World Institute for Development Economic Research, United Nations University.

Bashir, Mohammad. 2009. Asian Crime Syndicates Invading PNG-Officers. Post Courier, 3 April 2009.

Baxter, Michael. 2001. Enclaves or Equity: The Rural Crisis and Development Choice in Papua New Guinea. International Development Issues No. 54. Canberra: AusAID.

Belshaw, C. S. 1964. Under the Ivi Tree: Society and Economic Growth in Rural Fiji. London: Routledge and Kegan Paul.

Borrey, Anou. 2000. Sexual Violence in Perspective: The Case of Papua New Guinea. In Reflections on Violence in Melanesia, ed. Sinclair Dinnen and Allison Ley, 105-118. Annandale: Hawkins Press and Canberra: Asia Pacific Press.

Bourke, R. M. 2008. The Poorest People Stay in Rural PNG. The National, 11 June 2008.

Buchanan-Aruwafu, Holly, with Albert Komara, Gennie Koronos, Rory Sitapai, Rosely Roy Nana. 2002. Strategies and Framework for Targeting Youth: Advising with PNG Youth on HIV/AIDS. Milestone No. 37. November 2002. National HIV/AIDS Support Project (NHASP)

Buchanan-Aruwafu, Holly. 2007. Youth Vulnerability to HIV in the Pacific. In Carol Jenkins and Holly Buchanan-Aruwafu, Cultures and Contexts Matter: Understanding and Preventing HIV in the Pacific, 71-130. Manila: Asian Development Bank.

Callick, Rowan. 2009. Corruption Fear in PNG Project: Luke Fletcher. The Australian, 20 October 2009.

CAP (Commission on AIDS in the Pacific). 2009. Turning the Tide: An OPEN Strategy for a Response to AIDS in the Pacific. Suva: Commission on AIDS in the Pacific. 
Chandy, Laurence. 2009. Linking Growth and Poverty Reduction in Papua New Guinea. Lowy Institute Analyses, September 2009. Sydney: Lowy Institute.

Chao, Sister J. P. 1989. A New Sense of Community: Perspectives from a Squatter Settlement. In The Ethics of Development, 17th Waigani Seminar, vol. 5: In Search of Justice, ed. C. Thirlwall and P. J. Hughes, 88-106. Port Moresby: University of Papua New Guinea Press.

Dinnen, S. and John Braithwaite. 2009. Reinventing Policing through the Prism of the Colonial Kiap. Policing and Society, 19 (2): 161-173.

Dinnen, S. and E. Thompson. 2009. State Society and the Gender of Gun Culture in Papua New Guinea. In Sexed Pistols: The Gendered Impacts of Small Arms and Light Weapons, ed. Vanessa Farr, Henri Myrttinen and Albrecht Schnabel, 143-176. Tokyo, New York and Paris: United Nations University Press.

Dinnen, Sinclair. 2001. Law and Order in a Weak State: Crime and Politics in Papua New Guinea. Adelaide: Crawford House Publishing.

Dupont, Stephen. 2005. Raskols. Limited edition of photographic portraits, held in the National Library of Australia, Canberra. www.stephendupont.com

Ellsberg, Mary, Christine Bradley, Andrew Egan, Amy Haddad. 2008. Violence against Women in Melanesia and East Timor: Building on Global and Regional Promising Approaches. Canberra: AusAID.

Engels, John. 2008. Success Stories from Papua New Guinea: Tingim Laip. Waigani: Family Health International.

Epstein, Helen. 2007. The Invisible Cure: Why We are Losing the Fight against AIDS in Africa. New York: Picador.

Fife, Wayne. 1995. Models for Masculinity in Colonial and Postcolonial Papua New Guinea. The Contemporary Pacific 7 (2): 277-302.

Finney, B. 1973. Polynesian Peasants and Proletariats. Cambridge, Massachusetts: Schenkman Publishing Company.

Fox, Liam. 2009. PNG's HIV Pledge on Shaky Ground. Australian Broadcasting Commission, 5 December 2009.

France, A. 1998. 'Why Should We Care?' Young People, Citizenship and Questions of Responsibility. Journal of Youth Studies 1 (1): 97-111.

Garap, Sarah. 2000. Struggles of Women and Girls. In Reflections on Violence in Melanesia, ed. Sinclair Dinnen and Allison Ley, 159-171. Leichardt and Canberra: Hawkins Press and Asia Pacific Press. 
Gerawa, Maureen. 2004. Shocking News. Post-Courier, 29 September 2004.

Goddard, M. 2005. The Unseen City: Anthropological Perspectives on Port Moresby, Papua New Guinea. Canberra: Pandanus Books.

Goddard, M. 2009. Substantial Justice: An Anthropology of Village Courts in Papua New Guinea. New York and Oxford: Berghahn Books.

Guy, Sandy and David Crofts. 2000. Papua New Guinea: Epidemic on Our Doorstep. The Mercury, 26 February 2000.

Haley, Nicole. 2008. Sung Adornment: Changing Masculinities at Lake Kopiago, Papua New Guinea. The Australian Journal of Anthropology, 19 (2): 213-229.

Hammar, L. 1998. AIDS, STDs, and Sex Work in Papua New Guinea. In Modern Papua New Guinea, ed. Laura Zimmer-Tamakoshi, 257-296. Kirksville, MO: Thomas Jefferson University Press.

Harris, Bruce M. 1988. The Rise of Rascalism: Action and Reaction in the Evolution of Rascal Gangs. IASER Discussion Paper No. 54. Port Moresby: Institute of Applied Social and Economic Research.

Hayward-Jones, Jenny. 2008. Beyond Good Governance: Shifting the Paradigm for Australian Aid to the Pacific Islands Region. Policy Brief, September 2008. Sydney: Lowy Institute for International Policy.

HELP (HELP Resources Inc.). 2005. A Situational Analysis of Child Sexual Abuse and the Commercial Sexual Exploitation of Children in Papua New Guinea. Prepared by HELP Resources, Inc., with the support of UNICEF PNG. January 2005.

Helve, Helena and Claire Wallace. 2001. Youth, Citizenship and Empowerment. Aldershot: Ashgate.

Herdt. G., ed. 1982. Rituals of Manhood: Male Initiation in Papua New Guinea. Berkeley: University of California Press.

Herdt,. G. 1984. Ritualized Homosexual Behavior in the Male Cults of Melanesia, 1862-1983: An Introduction. In Ritualized Homosexuality in Melanesia, ed. G. Herdt, 1-81. Berkeley: University of California Press.

Herdt, Gilbert and Stephen C. Leavitt. 1998. Introduction: Studying Adolescence in Contemporary Pacific Island Communities. In Adolescence in Pacific Island Societies, ed. Gilbert Herdt and Stephen C. Leavitt, 3-26. Pittsburgh: University of Pittsburgh Press. 
Civic Insecurity

Hukula, Fiona. 1999. Women and Security in Port Moresby. NRI Discussion Paper no. 92. Boroko: National Research Institute.

Hukula, Fiona. 2005. Rape and Social Identity. NRI Discussion Paper No. 100. Boroko: The National Research Institute.

INA (Institute of National Affairs). 2004. Report of the Royal Papua New Guinea Constabulary Administrative Review Committee to the Minister for internal Security Hon. Bire Kimisopa. Port Moresby: Institute of National Affairs.

James, Paul, Victoria Stead, Yaso Nadarajah, Karen Haive. 2009. Projecting Community Life, themed issue, Local Global: Identity, Security, Community, 5 .

Jenkins, C. 1996. The Homosexual Context of Heterosexual Practice in Papua New Guinea. In Bisexualities and AIDS: International Perspectives, ed. P. Aggleton, 191-206. London: Taylor and Francis.

Jenkins, C and M. Alpers. 1996. Urbanization, Youth and Sexuality: insights for an AIDS Campaign for Youth in Papua New Guinea. PNG Medical Journal. 39 (3): 248-251.

Joku, Harlyne. 2009. 2 Million Condoms Go to Waste! Post-Courier, 4 March 2009.

Jolly, M. 1992. Spectres of Inauthenticity. The Contemporary Pacific, 4 (1): 49 72.

Jolly, M. and M. Macintyre, eds. 1989. Family and Gender in the Pacific: Domestic Contradictions and the Colonial Impact. Cambridge: Cambridge University Press.

Jolly, M. and N. Thomas. 1992. Introduction. In The Politics of Tradition in the Pacific, ed. M. Jolly and N. Thomas, special issue of Oceania, 62 (4): 241-248.

Kalichman, Seth. 2009. Denying AIDS: Conspiracy Theories, Pseudoscience and Human Tragedy. New York: Copernicus Books.

Kay, P. 1971. Urbanisation in the Tahitian Household. In Polynesia: Readings on a Culture Area, ed. A. Howard, 319-329. Scranton: Chandler Publishing Co.

Kelly, Angela, Frances Akuani, Barbara Kepa, Lawrencia Pirpir, Agnes Mek, Martha Kupul, Rebecca Emori, Somu Nosi, Lucy Walizopa, Brneda Cangah, Kritoe Keleba. 2008. Young People's Attitudes towards Sex and HIV in the Eastern Highlands of Papua New Guinea. Monograph 1/2008. Sydney: National Centre for HIV Social Research. 
Kewa, Christina. 2007. Being a Woman in Papua New Guinea: From Grass Skirts and Ashes to Education and Global Changes. Nelson, NZ: The Copy Press.

Kidu, Carol. 2002. A Remarkable Journey. Sydney: Longman.

Kidu, Carol. 2008a. Challenges and Opportunities for Papua New Guinea: A Reflection on Changing Times. Presentation to the Oceanic Connections Conference, Australian National University, Canberra, 18 April 2008.

Kidu, Carol. 2008b. The Power of Partnerships: Reflections on Addressing Papua New Guinea's Social Challenges. Presentation to the Lowy Institute, Sydney, 7 May 2008. Available http://lowyinstitute.org/ (accessed 27 April 2010).

Leavitt, Stephen C. 1998. The Bikhet Mystique: Masculine Identity and Patterns of Rebellion among Bumbia Adolescent Males. In Adolescence in Pacific Islands Societies, ed. Gilbert Herdt and Stephen C. Leavitt, 173-194. Pittsburgh, PA: University of Pittsburgh Press.

Lepani, 2007. 'In the Process of Knowing': Making Sense of HIV and AIDS in the Trobriand Islands of Papua New Guinea. PhD thesis, Canberra: The Australian National University.

Lepani, Katherine. 2008. Mobility, Violence and the Gendering of HIV in Papua New Guinea. The Australian Journal of Anthropology, 19 (2): 150-164.

Levantis, Theodore. 2000. Crime Catastrophe-Reviewing Papua New Guinea's most Serious Social and Economic Problem. Pacific Economic Bulletin 15 (2): 130-142.

Lewis, Ione. 2009. How is HIV transmission in PNG influenced by violence against women and attitudes towards condoms? In AIDS, Belief and Culture in PNG, ed. Hermann Spingler, special issue of Catalyst, 39 (2): 29-55.

Lornie, David. 2008. Vavine's Curse. Darnum, VIC: Dwyers Pacific Press Pty Ltd.

Macintyre, Martha. 2008. Police and Thieves, Gunmen and Drunks: Problems with Men and Problems with Society in Papua New Guinea. The Australian Journal of Anthropology, 19: 2, 179-193.

Malinowski, Bronislaw. 1932. The Sexual Lives of Savages in North-western Melanesia: An Ethnographic Account of Courtship, Marriage and Family Life among the Natives of the Trobriand Islands. London: Routledge and Kegan Paul.

McLeod, Abby, 2008. Leadership Models in the Pacific. State Society and Governance in Melanesia Discussion Paper, 2009/6. Canberra: Australian National University. 
Millan, John, William Yeka, Walter Obiero, Joachim Pantumari. 2006. HIV/AIDS Behavioural Surveillance Survey within High Risk Settings: Papua New Guinea: BSS Round 1. [Port Moresby]: National AIDS Council Secretariat and National HIV/AIDS Support Project.

Monasch, Roeland and Mary Mahy. 2006. Young People: The Centre of the HIV Epidemic. In Preventing HIV/AIDS in Young People: A Systematic Review of the Evidence from Developing Countries, UNAIDS Inter-agency Task Team on Young People, 15-36. Geneva: World Health Organization.

Monsell-Davis, M. 1987. At Home in the Village: Youth and Community in Nabuapaka. In Youth and Society: Perspectives from Papua New Guinea, ed. Maev O'Collins, 65-80. Canberra: Department of Political and Social Change, Australian National University.

Monsell-Davis, M. 1985. The Village Entrepreneur: Business Man or Villager? Extension Studies Department. Port Moresby: University of Papua New Guinea [An abridged version appeared as: Rural Entrepreneurs need Expert Advice, The Times of PNG, 7 April 1985].

Monsell-Davis, M. 1993a. Urban Safety-net or Disincentive? Wantoks and Relatives in the Urban Pacific. Canberra Anthropology 16 (2): 45-66.

Monsell-Davis, M. 1993b. Micro-enterprises and Rural Development: Global Economy, Local Initiatives and Local Constraints. Department of Anthropology. Port Moresby: University of Papua New Guinea.

Monsell-Davis, M. 1994. What is this Thing Called 'Family'? Discussion Paper for Symposium on 'The Family'. Sociology Department. Suva: University of the South Pacific.

Monsell-Davis, M. 1998a. Youth and Social Change in the Pacific. Draft paper. MacMillan Brown Centre for Pacific Studies. Christchurch: Canterbury University.

Monsell-Davis, M. 1998b. Education and rural development: social considerations in expanding high school education to all. In Modern Papua New Guinea, ed. Laura Zimmer-Tamakoshi, 315-332. Kirksville, MO: Thomas Jefferson University Press.

Monsell-Davis, M. 2000. Social Change, Contradictions, Youth and Violence. In Reflections on Violence in Melanesia, ed. S. Dinnen and A. Ley, 209-222. NSW and Canberra: Hawkins Press/Asia Pacific Press.

Monsell-Davis, M. 2005. 'Don't Ask for Biscuits': Economic Decline and Social Change in a Coastal Papuan Village. In A Polymath Anthropologist: Essays 
in Honour of Ann Chowning, ed. Claudia Gross, H. Lyons and D. Counts, 121-130. Auckland: Research in Anthropology and Linguistics, Monograph Series Vol. 6.

Moore, Clive. 2003. New Guinea: Crossing Boundaries and History. Honolulu: University of Hawai'i Press.

Muri, David. 2009. 'I was raped.' 'Big man' lures school girl, 17. The National, 12 February 2009.

Naemon, Anna Sirimai. 2009. Behaviours that Put Female Youth at Risk of Human Immunodeficiency Virus and Sexually Transmitted Infections in Gerehu, Port Moresby, Papua New Guinea. Masters thesis. Wellington: Victoria University.

Nalu, Malum. 2009. Massive Scam within AIDS Council: Barter. The National, 6 March 2009.

Narokobi, Bernard, et al. 1980. The Melanesian Way: Total Cosmic Vision of Life. [Port Moresby]: Institute of Papua New Guinea Studies.

NACS (National AIDS Council Secretariat) and Partners. 2008. Papua New Guinea: UNGASS 2008 Country Progress Report: Reporting Period: January 2006-December 2007. Port Moresby: National AIDS Council.

NSO (National Statistical Office). 2003. Papua New Guinea 2000 Census. Port Moresby: National Statistical Office.

Ninkama, Kristoffa. 2009. 40 Years of Complete Neglect. Post-Courier, 12 March 2009.

NSRRT (National Sex and Reproduction Research Team and Carol Jenkins). 1994. National Study of Sexual and Reproductive Knowledge and Behaviour in Papua New Guinea. Goroka: PNG Institute of Medical Research, Monograph 10.

NYC (National Youth Commission). 2007. National Youth Policy of Papua New Guinea 2007-2017. Port Moresby: National Youth Commission of Papua New Guinea.

NZPPD. 2010. Making Maternal Health Matter: Report of the New Zealand Parliamentarians' Group on Population and Development. Open Hearing on Maternal Health in the Pacific. [Wellington]: The New Zealand All-Party Parliamentary Group. 
PNG (Papua New Guinea). 2007. A Just, Safe and Secure Society: A White Paper on Law and Justice in Papua New Guinea. March 2007. Presented to Parliament by the Minister for Justice Bire Kimisopa. Port Moresby: Office of the Secretary for Justice and Attorney General.

PNG (Papua New Guinea) and UN (United Nations). 2004. Millennium Development Goals: Progress Report for Papua New Guinea. [place of publication, publisher, not specified]

PNG (Papua New Guinea) JAG (Justice Advisory Group). 2008. Law \& Justice Sector: Urban Crime Victimisation in Papua New Guinea, 2004-2008: A Synthesis. [place of publication, publisher, not specified]

PNG (Papua New Guinea) NSO (National Statistical Office), 2003. 2000 National Census: National Report. Port Moresby: National Statistical Office

Renkin, Lisa and Chad Hughes. 2006. HIV: The Predicament and the Potential of Young People in Papua New Guinea. Youth Advisors' Report. (unpublished report, reprinted with permission from the National AIDS Council of PNG).

Rubinstein, D. 1994. Changes in the Micronesian Family Structure Leading to Alcoholism, Suicide and Child Abuse and Neglect. Micronesian Counsellor, Occasional Paper 15.

SCiPNG (Save the Children in Papua New Guinea). [2008]. Youth Outreach Project: Knowledge, Attitude and Practice Survey in the Eastern Highlands and Madang Provinces of Papua New Guinea. Unpublished report.

Sahlins, M. 1963. Poor Man, Rich Man, Big Man, Chief: Political Types in Melanesia and Polynesia. Comparative Studies in Society and History 5 (3): 285-303.

Sikani, Richard. 1997. 'Live to Steal and Steal to Live': Juveniles and Economic Crime. Preliminary Paper No. 3. Port Moresby: Political and Legal Studies Division, National Research Institute.

Sivusia-Joyce, Barbara, Henry Koi, Hazel Mamae. 2004. Evaluation of the Impact and Effectiveness of the PNG HIV/AIDS Awareness Program in Selected Secondary Schools and High Schools in the National Capital District. [Port Moresby]: National Research Institute.

SPC (Secretariat of the Pacific Community). 2010. Pacific Island PopulationsEstimates and Projections of Demographic Indicators for Selected Years. Updated February 2010.

Strathern, A. 1993. Violence and Political Change in Papua New Guinea. Pacific Studies 16 (4): 41-60. 
Strathern, M. 1975. Report on Questionnaire Relating to Sexual Offences as Defined in the Criminal Code, Report Prepared for the Department of Law, New Guinea Research Unit, Boroko.

UNAIDS ITTYP (Inter-agency Task Team on Young People). 2006. Preventing HIV/AIDS in Young People: A Systematic Review of the Evidence from Developing Countries. Geneva: World Health Organization.

UNAIDS. 2009. AIDS Epidemic Update December 2009. Geneva: UNAIDS.

UNDP (United Nations Development Program). 2009. MDG Scorecard: MDG Status at a Glance. Suva: UNDP Pacific Centre.

UNICEF. 1995. The State of Pacific Children 1995. Suva: UNICEF.

UNICEF. 1998. State of Pacific Youth Report 1998. Suva: UNICEF.

UNICEF. 2005. Children and HIV/AIDS in Papua New Guinea. Port Moresby: UNICEF.

Waiko, John Dedamo. 1993. A Short History of Papua New Guinea. Melbourne: Oxford University Press.

Wardlow, Holly. 2006. Wayward Women: Sexuality and Agency in a New Guinea Society. Berkeley: University of California Press.

Werf, Janko van der. 2008. 'We Live like in a War': An Anthropological Investigation into Criminal Gangs in the Rural and Urban Areas of Papua New Guinea. Melanesian Mission Studies No. 3. Goroka: Melanesian Institute.

Whiteside, Alan. 2008. HIV/AIDS: A Very Short Introduction. Oxford: Oxford University Press.

Worthman, Carol M. 1998. Adolescence in the Pacific: A Biosocial View. In Adolescence in Pacific Islands Societies, ed. Gilbert Herdt and Stephen C. Leavitt, 27-52. Pittsburgh, PA: University of Pittsburgh Press.

WHO (World Health Organization). 2008. World Health Statistics 2008. Geneva: WHO.

Zimmer-Tamakoshi, L. 1990. Nationalism and Sexuality in Papua New Guinea. Pacific Studies 16 (4): 20-48.

Zimmer-Tamakoshi, L. 1997. Wild Pigs and Dog Men: Rape and Domestic Violence as 'Women's Issues' in Papua New Guinea. In Gender in CrossCultural Perspective, ed. C. Bretteland and C. Sargent, 538-553. Upper River: Prentice Hall. 